\title{
28 Research Square \\ Growth of Palm Trees and Woods in the Urban Environment
}

Valéria de Fatima Silva ( $\sigma$ valeria.fatima@ufv.br)

Universidade Federal de Vicosa

Laércio Antônio Gonçalves Jacovine

Universidade Federal de Vicosa

Angeline Martini

Universidade Federal de Viçosa

Carlos Moreira Miquelino Eleto Torres

Universidade Federal de Vicosa

Isabella Salgado Faustino

Universidade Federal de Vicosa

Mariany Filipini de Freitas

Universidade Federal de Vicosa

Daniel Leal de Carvalho

Universidade Federal de Vicosa

Cassio Luciano Vieira de Castro

Universidade Federal de Vicosa

Andressa Marques da Silva

Universidade Federal de Vicosa

Pedro Henrique Santos Mota

Universidade Federal de Vicosa

\section{Research Article}

Keywords: Average annual incremente, Forest management, Urban afforestation, Urban planning

Posted Date: December 1st, 2021

DOl: https://doi.org/10.21203/rs.3.rs-909658/v1

License: (a) (i) This work is licensed under a Creative Commons Attribution 4.0 International License.

Read Full License 


\section{Abstract}

Trees in the urban environment provide several ecosystem benefits to the population, such as decreasing temperature, increasing humidity, shading, improving air quality, as well as physical and mental wellbeing. These can be enhanced through the knowledge of the growth of the trees in function of the characteristics of the place where they are inserted. Thus, the objective was to estimate the growth in diameter, height and volume of forest species in the urban environment, in Viçosa, Minas Gerais, Brazil. For this, woody individuals and palm trees present in the urban afforestation of the headquarters campus of the Federal University of Viçosa were selected based on age and had their diameter, breast height and height measured. Allometric equations specific to the study site were used to estimate their volume, and through the relationship with age, the average annual increment was obtained. Woody individuals showed a growth rate in volume of 0,0279 $\pm 0,0274 \mathrm{~m}^{3}$ year- 1 and palm trees, 0,0139 $\pm 0,0119 \mathrm{~m}^{3}$ year- 1 . The differences in the average annual increase in volume found between woody individuals and palm trees may be due to morphological differences that affect the secondary growth of individuals. The growth rate of trees in the urban environment is higher when compared to those in forest fragments and experimental plantings. The decrease in growth rates with increasing age was expected due to the relationship between them being of the non-linear type, following a sigmoidal model.

\section{Introduction}

The use of trees and palms to compose urban afforestation provides a healthier physical environment for the population (ROSSATTO; TSUBOY; FREI, 2008). Improving the quality of the local microclimate with decreasing temperature; elevation of humidity; environmental preservation; attraction of avifauna; reduction of noise and visual pollution levels; natural barrier against winds; revaluation of contemporary spaces; scenic beauty and physical and mental well-being to the population are benefits of urban afforestation (GENGO; HENKES, 2013). Thus, afforestation d this environment is also responsible for improving adverse conditions, ensuring better housing in cities (LACY; SHACKLETON, 2014).

These benefits depend on the abundance, size and growth of individuals and, in order to potentiate them, it is necessary to improve the understanding of how trees develop in the urban environment, which is still a gap, especially for native species (LACY; SHACKLETON, 2014; EVANS et al., 2017). This information is relevant also to the appropriate selection of species, choice of location of planting, spacing the plants, distances relative to other urban components, direction for shading, and necessary silvicultural practices (Semenzato; CATTANEO; DAINESE 2011; PRETZSCH et al., 2015).

The growth rates of urban trees and palms vary depending on the species, local climatic condition, volume, porosity and soil chemistry, canopy irradiance and air quality (IAKOVOGLOU et al., 2001; MORGENROTH; BUCHAN; SCHARENBROCH, 2013; BOUKILI et al., 2017; FIGUEIREDO FILHO et al., 2017). Paving the soil surface is a limiting factor for growth due to compaction and adverse conditions generated, such as reduced aeration, low water infiltration and less accumulation of organic matter (VISWANATHAN et al., 2011; LAWRENCE et al., 2012). Allied to this, the planting conditions, management 
strategies adopted, such as irrigation and pruning, and the people who benefit from urban trees also influence growth and, thus, there may be differences within and between locations (SEMENZATO; CATTANEO; DAINESE, 2011; VOGT et al., 2015). Understanding the annual rates at which trees and palms grow in the urban environment is essential to support correct estimates of the provision of ecosystem services over time, despite this, few studies have made these estimates (VAZ MONTEIRO; LEVANIČ; DOICK, 2017). Thus, the aim of this study was to investigate the growth of different species of palm and woody species in the urban environment, in Viçosa, Minas Gerais, Brazil. The hypotheses analyzed were that i) palm and woody species show different growth rates; ii) the growth rate differs, within each previous group, depending on the species, and iii) native species show a higher growth rate than exotic species.

\section{Methods}

The forest, palm and woody species present in the access roads, parking lots and lawns on the campus of the Federal University of Viçosa in Viçosa, Minas Gerais, Brazil ( $20^{\circ} 45^{\prime} 14^{\prime \prime}$ S and $42^{\circ} 45^{\prime} 53^{\prime \prime}$ W) were evaluated. The region's vegetation is classified as Montana seasonal semideciduous forest (IBGE, 2012), with Cwa climate (Köppen) and concentrated rainfall between the months of October and March. On average, the average daily maximum and minimum temperature and annual precipitation were $27.2^{\circ} \mathrm{C}, 16^{\circ} \mathrm{C}$ and $1184.9 \mathrm{~mm}$, respectively (UFV, 2018).

The selection of the studied species was based on the knowledge of the age of the individuals, this being the first stage of the research. The age was estimated through orthophotocards from the city of Viçosa, available in the collection of the Department of Forestry at UFV, historical records of the institution and also with images of Google Earth Pro ${ }^{\circledR}$.

The age (I/nd) attributed to the individuals identified in the images was obtained by $\mathrm{I} / n d=2018$ - (AP + AA) / 2, being AP: year of the orthophoto/image where the individual was identified and; AA: year of the orthophotocarte/image immediately preceding it. The conversion was necessary since, it is not known exactly when, between the two images (AP and $A A$ ), the individual was planting, thus adopting the average age of the period.

Individuals whose age was estimated and had more than 5 centimeters in diameter at chest height (DBH), were inventoried between April and May 2018. The total height ( $\mathrm{Ht}$ ), in meters, was measured with a Vertex Laser 5 Hypsometer and the Circumference at Chest Height (CAP), in centimeters, obtained with a measuring tape and converted to DAP by the expression DAP = CAP / $\pi$. The botanical identification was carried out with the collection of vegetative material for analysis in the UFV Dendrology sector .

Volumetric equations of Shumacher and Hall were adjusted based on rigorous cubing data performed in the same study site in 2010. The volume of palm and woody individuals was obtained, respectively, by $\mathrm{V}_{i}=0.00006067 *\left(\mathrm{DBH}_{i}\right)^{1.953 *}\left(\mathrm{Ht}_{i}\right)^{1.006}\left(\mathrm{R}^{2}=99.17 \%\right)$ and $\mathrm{V}_{i}=0.0005425 *\left(\mathrm{DBH}_{i}\right)^{1.6152524}$ * $\left(\mathrm{Ht}_{i}\right)$ $0.7395611\left(\mathrm{R}^{2}=79.40 \%\right)$, where $\mathrm{V}_{i}$ : o volume of the $i$ - th individual, in $\mathrm{m}^{3} ; \mathrm{DBH}_{i}$ : diameter at chest height of 
the $i$ - th individual, in centimeters $\mathrm{e} \mathrm{Ht}_{i}$ : total height of the $i$ - th individual, in meters ( Brianezi et al., 2013 adapted) .

The growth of individuals was estimated with the Average Annual Volume Increase $\left(I M A_{V}-m^{3}\right.$ year $\left.{ }^{-1}\right)$, obtained by IMA $\mathrm{IV}_{i}=\mathrm{V}_{i} / I_{\operatorname{Ind} i}$, with IMA $\mathrm{IV}_{i}$ : the average annual increase in volume of the $i$ - th individual, in $\mathrm{m}^{3}$ year ${ }^{-1} ; \mathrm{V}_{i}$ : the volume of the $i$ - th individual, in $\mathrm{m}^{3}, \mathrm{e} ; \mathrm{I}_{\text {Ind }}$ : the age of the $i$ - $t h$ individual, in years. The

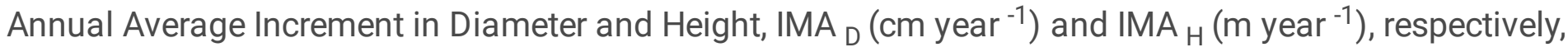
were obtained through the ratio between the value obtained in the forest inventory and the individual's age.

The average increments in volume, diameter and height according to the origin of the species, native to the Atlantic Forest, native to Brazil or exotic, were analyzed with ANOVA in a completely randomized design. The Tukey test was applied when there was a rejection of the null hypothesis. The analyzes of variance and comparisons between the averages were performed with confidence intervals with $99 \%$ certainty. The statistical procedures were performed using the $R$ software.

\section{Results}

Through the forest inventory, 1,888 individuals were evaluated, $86.97 \%$ belonging to the woody group. Licania tomentosa, Michelia champaca and Archontophoenix alexandrae were the species with the largest number of individuals (Table 1). Michelia champaca, Delonix regia and Archontophoenix alexandrae, on average, presented the oldest individuals with 93 years, 60 years and 53.8 years, respectively (Table 1 ).

Table 1. Number of individuals (Ind), average DBH (DBHm, in $\mathrm{cm}$ ), average height ( $\mathrm{Htm}$, in $\mathrm{m}$ ) and average volume $\left(\mathrm{Vm}\right.$, in $\left.\mathrm{m}^{3}\right)$, by age range (I, in years), of the species evaluated in Viçosa, Minas Gerais, Brazil, in 2018 


\begin{tabular}{|c|c|c|c|c|c|}
\hline Species & $\mathrm{I}$ & Ind & $\mathrm{DBH}_{\mathrm{m}}$ & $\mathrm{Ht}_{\mathrm{m}}$ & $V_{m}$ \\
\hline \multicolumn{6}{|l|}{ Woody } \\
\hline Albizia lebbeck (L.) Benth. & $20-40$ & 3 & 40.98 & 17.4 & 1.9127 \\
\hline Anadenanthera macrocarpa (Benth.) Brenan & $20-40$ & 6 & 54.22 & 26.9 & 4.2408 \\
\hline Araucaria columnaris (JR Forst.) Hook. & $20-40$ & 3 & 40.26 & 13.9 & 1.7147 \\
\hline Bauhinia forficata Link & $20-40$ & 140 & 27.17 & 8.5 & 0.6652 \\
\hline Bombacopsis glabra (Pasq.) A. Robyns & $20-40$ & 4 & 30.25 & 11.2 & 0.9984 \\
\hline Bougainvillea glabra Choisy & $20-40$ & 15 & 11.19 & 6.9 & 0.1809 \\
\hline Delonix regia (Bojer ex Hook.) Raf. & $60-80$ & 44 & 80.84 & 11.8 & 4.3474 \\
\hline \multirow[t]{2}{*}{ Filicium decipiens (Wight \& Arn.) Thwaites } & $0-20$ & 40 & 15.39 & 9.0 & 0.3864 \\
\hline & $20-40$ & 28 & 14.96 & 7.5 & 0.3041 \\
\hline \multirow[t]{2}{*}{ Handroanthus impetiginosus (Mart. ex DC.) Mattos } & $20-40$ & 62 & 26.26 & 16.1 & 1.1514 \\
\hline & $40-60$ & 3 & 37.27 & 21.4 & 2.1352 \\
\hline \multirow[t]{2}{*}{ Handroanthus serratifolius (Vahl) S. Grose } & $20-40$ & & & & \\
\hline & & 57 & 18.32 & 11.4 & 0.5041 \\
\hline Hibiscus rosa-sinensis L. & $40-60$ & 12 & 34.70 & 15.8 & 1.4581 \\
\hline Holocalyx balansae Micheli & $20-40$ & 9 & 17.07 & 6.4 & 0.2311 \\
\hline \multirow[t]{3}{*}{ Lagerstroemia indica L. } & $20-40$ & 6 & 30.68 & 14.6 & 1.2823 \\
\hline & $0-20$ & 25 & 9.28 & 6.4 & 0.0941 \\
\hline & $20-40$ & 72 & 12.82 & 7.3 & 0.1852 \\
\hline \multirow[t]{2}{*}{ Lagerstroemia speciosa (L.) Pers. } & $40-60$ & 19 & 24.93 & 7.3 & 0.5054 \\
\hline & $0-20$ & 28 & 16.81 & 9.1 & 0.4151 \\
\hline \multirow[t]{3}{*}{ Licania tomentosa (Benth.) Fritsch } & $20-40$ & 16 & 33.80 & 12.9 & 1.3051 \\
\hline & $0-20$ & 41 & 14.06 & 7.7 & 0.2667 \\
\hline & $20-40$ & 281 & 31.92 & 12.0 & 1.0751 \\
\hline \multirow[t]{2}{*}{ Ligustrum lucidum W.T.Aiton } & $40-60$ & 104 & 36.54 & 14.0 & 1.4348 \\
\hline & $20-40$ & 9 & 39.81 & 11.0 & 1.3410 \\
\hline Litchi chinensis Sonn. & $40-60$ & 9 & 36.27 & 9.9 & 1.0856 \\
\hline Mangifera indica L. & $20-40$ & 3 & 33.51 & 9.8 & 1.4619 \\
\hline
\end{tabular}




\begin{tabular}{|c|c|c|c|c|c|}
\hline Michelia champaca L. & $20-40$ & 6 & 24.33 & 10.6 & 1.9185 \\
\hline \multirow[t]{3}{*}{ Murraya paniculata (L.) Jack } & $\begin{array}{l}80- \\
100\end{array}$ & 192 & 33.37 & 7.2 & 0.7157 \\
\hline & $0-20$ & 23 & 10.08 & 3.8 & 0.0808 \\
\hline & $20-40$ & 60 & 11.91 & 4.0 & 0.1188 \\
\hline $\begin{array}{l}\text { Paubrasilia echinata (Lam.) Gagnon, H.C. Lima \& G.P. } \\
\text { Lewis }\end{array}$ & $40-60$ & 33 & 11.30 & 4.1 & 0.0931 \\
\hline Peltophorum dubium (Spreng.) Taub. & $20-40$ & 14 & 12.93 & 8.0 & 0.2589 \\
\hline \multirow[t]{2}{*}{ Poincianella pluviosa (DC.) L.P. Queiroz } & $20-40$ & 7 & 33.68 & 12.4 & 1.2668 \\
\hline & $0-20$ & 8 & 18.89 & 8.5 & 0.3941 \\
\hline Spathodea campanulata P. Beauv. & $20-40$ & 76 & 30.85 & 13.6 & 1.3527 \\
\hline Tabebuia roseoalba (Ridl.) Sandwith & $40-60$ & 70 & 55.34 & 13.4 & 2.8216 \\
\hline Terminalia catappa L. & $20-40$ & 3 & 37.35 & 9.8 & 1.0862 \\
\hline \multirow[t]{2}{*}{ Tibouchina granulosa (Desr.) Cogn } & $20-40$ & 39 & 28.62 & 11.2 & 0.9492 \\
\hline & $0-20$ & 12 & 10.97 & 6.2 & 0.1754 \\
\hline \multicolumn{6}{|l|}{ Palm Trees } \\
\hline Acrocomia aculeata (Jacq.) Lodd. ex Mart. & $20-40$ & 5 & 33.99 & 14.8 & 0.8924 \\
\hline \multirow{4}{*}{$\begin{array}{l}\text { Archontophoenix alexandrae (F. Muell.) H. Wendl. e } \\
\text { Drude }\end{array}$} & $0-20$ & 12 & 20.52 & 11.2 & 0.2622 \\
\hline & $20-40$ & 12 & 21.62 & 11.2 & 0.2945 \\
\hline & $40-60$ & 27 & 24.02 & 14.1 & 0.4797 \\
\hline & $60-80$ & 136 & 23.40 & 15.1 & 0.4738 \\
\hline \multirow[t]{3}{*}{ Syagrus romanzoffiana (Cham.) Glassman } & $0-20$ & 32 & 24.40 & 9.6 & 0.3979 \\
\hline & $20-40$ & 17 & 25.17 & 10.4 & 0.3735 \\
\hline & $40-60$ & 5 & 30.23 & 19.2 & 0.9793 \\
\hline
\end{tabular}

Woody individuals presented an average annual increase in volume higher than that of palm trees, 0.02 $79 \pm 0.0274$ and $0.0139 \pm 0.0119 \mathrm{~m}^{3}$ year -1 respectively (Table 2 ). The same behavior was observed for the increase in diameter, however in height, the individuals of palm trees showed the highest average annual increase (Table 2). Individually, Anadenanthera macrocarpa and Mangifera indica presented the highest values of IMAv, $0.1588 \pm 0.0504 \mathrm{~m}^{3}$ year $^{-1}$ and $0.0959 \pm 0.0584 \mathrm{~m}^{3}$ year $^{-1}$, respectively, followed by the palm tree Acrocomia columnaris which presented equal IMAv at $0.0446 \pm 0.0056 \mathrm{~m}^{3}$ year $^{-1}$ (Table 2). 
Table 2. Average annual increment in Volume (IMAv, in $\mathrm{m}^{3}$ ), Diameter (IMAD, in $\mathrm{cm}$ ) and Height (IMAH, in $\mathrm{m})$ and standard deviation $\left(\mathrm{s}_{1}, \mathrm{~s}_{2}\right.$ and $\mathrm{s}_{3}$, respectively) of the species studied in Viçosa, Minas Gerais, Brazil, in 2018 


\begin{tabular}{|c|c|c|c|c|c|c|}
\hline Species & $\mathrm{IMA}_{\mathrm{V}}$ & $s_{1}$ & $I M A_{D}$ & $s_{2}$ & $\mathrm{IMA}_{\mathrm{H}}$ & $s_{3}$ \\
\hline Woody & 0.0279 & 0.0274 & 1.0130 & 0.5155 & 0.3780 & 0.2522 \\
\hline Albizia lebbeck & 0.0696 & 0.0181 & 1.5379 & 0.1540 & 0.6315 & 0.1306 \\
\hline Anadenanthera macrocarpa & 0.1588 & 0.0504 & 2.1251 & 0.2372 & 1.0181 & 0.1189 \\
\hline Araucaria columnaris & 0.0784 & 0.0180 & 2.0059 & 0.2542 & 0.6433 & 0.2401 \\
\hline Bauhinia forficata & 0.0242 & 0.0120 & 1.0637 & 0.2931 & 0.3090 & 0.0594 \\
\hline Bombacopsis glabra & 0.0363 & 0.0128 & 1.2440 & 0.1684 & 0.4073 & 0.0766 \\
\hline Bougainvillea glabra & 0.0066 & 0.0048 & 0.6222 & 0.3334 & 0.4097 & 0.2217 \\
\hline Delonix regia & 0.0725 & 0.0280 & 1.3838 & 0.2650 & 0.1968 & 0.0403 \\
\hline Filicium decipiens & 0.0253 & 0.0178 & 1.4377 & 0.6570 & 0.6503 & 0.3276 \\
\hline Handroanthus impetiginosus & 0.0419 & 0.0276 & 1.0438 & 0.3777 & 0.5791 & 0.2208 \\
\hline Handroanthus serratifolius & 0.0201 & 0.0161 & 0.7153 & 0.2852 & 0.3967 & 0.1504 \\
\hline Hibiscus rosa-sinensis & 0.0088 & 0.0038 & 0.6769 & 0.1528 & 0.2443 & 0.0684 \\
\hline Holocalyx balansae & 0.0466 & 0.0250 & 1.2484 & 0.3773 & 0.5303 & 0.1007 \\
\hline Lagerstroemia indica & 0.0086 & 0.0041 & 0.7514 & 0.2449 & 0.3743 & 0.1426 \\
\hline Lagrestroemia speciosa & 0.0470 & 0.0273 & 1.8910 & 0.4323 & 0.7480 & 0.2081 \\
\hline Licania tomentosa & 0.0317 & 0.0151 & 1.0640 & 0.3437 & 0.3957 & 0.1534 \\
\hline Ligustrum lucidum & 0.0445 & 0.0262 & 1.5477 & 0.6049 & 0.4067 & 0.1533 \\
\hline Litchi chinensis & 0.0532 & 0.0131 & 2.3080 & 1.3011 & 0.7830 & 0.7153 \\
\hline Mangifera indica & 0.0959 & 0.0584 & 3.3934 & 1.1623 & 1.7317 & 1.0115 \\
\hline Michelia champaca & 0.0077 & 0.0038 & 0.5012 & 0.1223 & 0.1070 & 0.0337 \\
\hline Murraya paniculata & 0.0048 & 0.0039 & 0.6520 & 0.3555 & 0.2183 & 0.1353 \\
\hline Paubrasilia echinata & 0.0120 & 0.0106 & 0.7364 & 0.2885 & 0.3768 & 0.1533 \\
\hline Peltophorum dubium & 0.0461 & 0.0276 & 1.3078 & 0.4247 & 0.4514 & 0.1152 \\
\hline Poincianella pluviosa & 0.0522 & 0.0460 & 1.4416 & 0.5167 & 0.6131 & 0.3296 \\
\hline Spathodea campanulata & 0.0571 & 0.0341 & 1.1748 & 0.3063 & 0.2753 & 0.0730 \\
\hline Tabebuia roseoalba & 0.0395 & 0.0157 & 1.3952 & 0.2912 & 0.3552 & 0.0615 \\
\hline Terminalia catappa & 0.0388 & 0.0252 & 1.2771 & 0.4374 & 0.4664 & 0.1759 \\
\hline Tibouchina granulosa & 0.0114 & 0.0099 & 0.8326 & 0.5349 & 0.3768 & 0.2217 \\
\hline
\end{tabular}




\begin{tabular}{|lllllll|} 
Palm tree & 0.0139 & 0.0119 & 0.8457 & 0.7313 & 0.4022 & 0.2426 \\
\hline Acrocomia aculeata & 0.0446 & 0.0056 & 1.6995 & 0.1055 & 0.7380 & 0.0478 \\
\hline Archontophoenix alexandrae & 0.0089 & 0.0040 & 0.5148 & 0.2581 & 0.3066 & 0.1396 \\
\hline Syagrus romanzoffiana & 0.0283 & 0.0146 & 1.9129 & 0.7889 & 0.7021 & 0.2626 \\
\hline
\end{tabular}

The native woody species from Brazil and the Atlantic Forest showed greater increments in relation to volume, diameter and height compared to exotic species (Table 3). The condition was also observed for the palm species, where the native ones of the Atlantic Forest surpassed the exotic ones (Table 3 ).

Table 3 . Average annual increase in volume (IMAv, in $\mathrm{m}^{3}$ ), Diameter (IMAD , in $\mathrm{cm}$ ) and Height (IMAH , in $\mathrm{m})$ and standard deviation $\left(\mathrm{s}_{1}, \mathrm{~s}_{2}\right.$ and $\mathrm{s}_{3}$, respectively) according to the origin of the species studied in Viçosa, Minas Gerais, Brazil, in 2018

\begin{tabular}{llllllll} 
Group & Origin & IMAV & $\mathbf{s}_{\mathbf{1}}$ & IMAD & $\mathbf{s}_{\mathbf{2}}$ & IMAH & \multicolumn{1}{c}{$\mathbf{s}_{\mathbf{3}}$} \\
\hline Woody & Exotic & $0.0240 \mathrm{~b}$ & 0.0291 & $0.9641 \mathrm{~b}$ & 0.6108 & $0.3264 \mathrm{c}$ & 0.2933 \\
\cline { 2 - 8 } & Native & $0.0360 \mathrm{a}$ & 0.0454 & $1.1596 \mathrm{a}$ & 0.6155 & $0.5115 \mathrm{a}$ & 0.3103 \\
& Brazil & & & & & & \\
\cline { 2 - 8 } & Native & $0.0299 \mathrm{a}$ & 0.0176 & $1.0266 \mathrm{a}$ & 0.3537 & $0.3973 \mathrm{~b}$ & 0.1625 \\
& Atlantic forest & & & & & & \\
\hline \multirow{2}{*}{ Palm Trees } & Exotic & $0.0089 \mathrm{a}$ & 0.0040 & $0.5148 \mathrm{~b}$ & 0.2581 & $0.3066 \mathrm{~b}$ & 0.1396 \\
\cline { 2 - 8 } & Native & $0.0297 \mathrm{a}$ & 0.0147 & $1.8948 \mathrm{a}$ & 0.7570 & $0.7051 \mathrm{a}$ & 0.2515 \\
& Atlantic forest & & & & & &
\end{tabular}

Means followed by the same letter in the column do not differ by Tukey 's test $(P<0.01)$.

The woody species showed the largest increases in volume, diameter and height in individuals aged between 20 and 40 years, and the palm group, up to the age of 20 , but maintaining growth beyond those ages (Chart 1). The wide variation for each age group is associated with the diversity of species in each group.

\section{Discussion}

The ecosystem services provided by urban afforestation depend on the size and health of trees and palms, which in these places can be negatively or positively affected by biotic, abiotic, climatic and anthropogenic factors (VAZ MONTEIRO; LEVANIČ; DOICK, 2017). The results of this study show that the growth in diameter, height and volume varies $\mathrm{m}$ according to the type of the studied plant, monocot or 
Eudicotiledonea with the origin of these species native of the Atlantic, Brazil or exotic and with age of individuals.

The woody plants and palm features ra $\mathrm{m}$ different growth rates $0.0279 \pm 0.0274$ and $0.0139 \pm 0.0119$ $\mathrm{m}^{3}$ ind $^{-1}$ year ${ }^{-1}$, respectively, mainly due to morphological differences that alter growth secondary education of individuals. In eudicotyledons, a group of woody species, secondary growth is characterized by the production of secondary xylem and the development of new protective tissues from the exchange rate (OLIVEIRA, 2011). In contrast, monocotyledons, such as palm trees, show an increase in stem diameter due to the division of fundamental tissues, these being primary growth structures (BOTÂNICO; ANGYALOSSY, 2013), which often limits the size of individuals compared to trees. Among tree species, the greatest increase in Anadenanthera macrocarpa may have occurred due to the adaptation of the species to adverse environmental conditions, with tolerance to shallow, compacted and even poorly drained soils (GONÇALVES et al., 2008). Murraya paniculata was the woody species with the lowest growth because it is a shrub (CHOWDHURY; BHUIYAN; YUSUF, 2008) with smaller size in diameter and height among all the analyzed species. Among the palm trees, the difference in the average increase in volume is due to the characteristic size of the species studied.

The average annual volumetric increase of woody species in the urban environment, $0.0279 \pm 0.0274 \mathrm{~m}^{3}$ ind $^{-1}$ year $^{-1}$, is higher than that found for Araucaria angustifolia, in two phytographic regions of Rio Grande do Sul, where there is a natural occurrence of the species with a maximum IMAv of $0.0198 \mathrm{~m}^{3}$ and $0.026 \mathrm{~m}^{3}$ (HESS; SCHNEIDER, 2010). In comparison with these data, the average growth of woody species in the urban area was lower than only a third fragment, which presented an average IMAv equal to $0.031 \mathrm{~m}^{3}$ year $^{-1}$ (HESS; SCHNEIDER, 2010). In planting at the Embrapa Experimental Field in the Western Amazon, an IMAv of $0.039 \mathrm{~m}^{3}$ ind $^{-1}$ year $^{-1}$ was estimated for the species Sclerolobium paniculata and between $0.019 \mathrm{~m}^{3}$ ind $^{-1}$ year ${ }^{-1}$ and $0.004 \mathrm{~m}^{3}$ ind $^{-1}$ year $^{-1}$ for Hymenae courbaril, Carapa guianensis, Bertholettia excelsa, Swietenia macrophylla, Copaifera multijuga, Cedrela odorata, Trattinickia burseraefolia and Dipteryx odorota (SOUZA et al., 2008). The volumetric growth of the studied species is greater in the urban environment than in forest fragments or plantations, which may be due to the absence or little competition. The lower density of trees in an area urban reduces the competition for light and other resources, thus fostering growth (McHALE et al., 2009), and consequently the provision of ecosystem services. Higher tree growth rates in the urban environment are also related to the climate in these locations, characterized by the effect of the heat island that causes higher temperatures in cities and can stimulate photosynthetic activity and extend the plant's growing season (PRETZSCH et al., 2017). It is important to note that the growth rate of trees and palms in the urban environment that are larger than in forest fragments also implies a faster aging of these individuals, thus indicating the need for their replacement and replanting (PRETZSCH et al., 2017). The existing variation also indicates the need to take into account the growth in the choice of species to compose urban afforestation.

Species of palm trees and woody native Atlantic Forest to and naturally occurring in Brazil showed higher average growth rates in diameter, height, and therefore volume. Native species also showed growth rates 
higher than the Exotic to s ex post when the $s$ at the same level of light, for example, in Connecticut, USA (MARTIN; KOBE, 2010). And exotic species may have shown lower values as a result of adverse environmental conditions, even with some plasticity for adaptation (MUÑOZ et al., 2015; MARTIN; CANHAM; KOBE, 2010). The temperature and precipitation significantly influence the growth of the trees (VITALI; BÜNTGEN; BAUHUS, 2018), and variations between the place of origin of the species can contribute to the reduction of the increase rates. These factors even affect the species' vitality (WILLIAMS et al., 2012), and can cause individuals to become senescent at an early stage. Climate change has altered the frequency of extreme events and this will continue to alter the growth of species, including native species, and it is important to include these effects in growth projections (ZIMMERMANN et al., 2009).

The groups of plants studied, palm and woody, showed variation in growth according to age, being for the first group, the highest rates in individuals up to 20 years old, and for the second, those between 20 and 40 years old. This variation stems from the fact that the relationship between diameter / height and age are non-linear and, in the juvenile stage, growth occurs at a faster rate (VAZ MONTEIRO; LEVANIČ; DOICK, 2017). The increase in tree dimensions with increasing age causes these individuals to reach stages with limited availability of growth factors, light, water and nutrients, which explains the growth patterns in sigmoidal form (KÖHL; NEUPARE; LOTFIOMRAN, 2017). At advanced ages, even at lower rates compared to the juvenile stage, urban trees and palms continue to grow, which has implications for the provision of ecosystem services and also for the need for management of individuals.

The ecosystem services provided by trees and palms in the urban environment are influenced by different factors, such as age, size, spacing, free area. The interception of rainwater, for example, varies according to the species and size of the individuals, with those with PAD close to $3.5 \mathrm{~cm}$ intercepting about $15.3 \%$, while those with $38.1 \mathrm{~cm}$ of DAP, can intercept up to 66.5\% (XIAO; McPHESON, 2002). Larger trees also tend to remove and store more carbon dioxide, in addition to retaining more airborne pollutants (GRATANI; VARONE, 2006). In Rome, trees with $\mathrm{DBH}$ ranging from $50-80 \mathrm{~cm}$, tend to remove, on average, $72 \%$ more carbon dioxide than those with DBH between 20-50 cm (GRATANI; VARONE, 2006). Thus, the growth rates of trees are indicative of carbon neutralization, expansion of the occupied area above and below ground and, consequently, provision of many ecosystem services (PRETZSCH et al., 2017). Thus, the sustainable management of the population will trees in a city can help mitigate the negative impacts of climate change and maximize the benefits generated, using, for this, information on growth rates, dimensional changes that depend on the age and situation (RÖTZER et al., 2019).

\section{Conclusions}

The growth rate of woody and palm forest species in the urban environment varies according to the type of plant, the origin of the species and the age of each individual, being, in general, faster than in forest fragments. This behavior brings several benefits to the local microclimate, such as interception of rainwater, shading, removal of carbon dioxide and interception of particles suspended in the air. On the 
other hand, this accelerated rhythm can anticipate the senescence of individuals causing the anticipation of their replacement.

The growth curves according to the age of the individuals is an important indicator of the spatialization, over time, of the provision of ecosystem services, since many are related to the supply of biomass in the trunk, or to the increase and renewal of leaves in the canopy. The growth of individuals being maintained, even at lower rates, with maturity, denotes their continued contribution to climate change.

Municipal afforestation plans must also enhance the inclusion of species naturally present in the region. These species have a higher growth rate than exotic species, establishing themselves more quickly in the area, in addition to being a form of ex situ conservation.

\section{Declarations}

Funding: Not applicable

Conflicts of interest/Competing interests: Not applicable

Availability of data and material: Not applicable

Code availability: Not applicable

Authors' contributions: Not applicable

Ethics approval: Not applicable

Consent to participate: Not applicable

Consent for publication: Not applicable

\section{References}

1. Botânico, M. P.; Angyalossy, V. (2013) Is the secondary thickening in palms always diffuse? Annals of the Brazilian Academy of Science 85: 1461-1472. https://doi.org/10.1590/0001-37652013108612

2. Boukili, V. K. S.; Bebber, D. P.; Mortimer, T.; Venicx, G.; Lefcourt, D.; Chandler, M.; Eisenberg, C. (2017) Assessing the performance of urban forest carbon sequestration models using direct measurements of tree growth. Urban Forestry and Urban Greening 24: 212-221. https://doi.org/10.1016/j.ufug.2017.03.015

3. Brianezi, D.; Jacovine, L.A.G.; Soares, C.P.B; Castro, R.V.O.; Basso, V.M. (2013) Equações alométricas para estimativa de carbono em árvores de uma área urbana em Viçosa - MG. Revista Árvore 37: 1073-1081. https://doi.org/10.1590/S0100-67622013000600009 
4. Chowdhury, J. U.; Bhuiyan, M. N. I.; Yusuf, M. (2008) Chemical composition of the leaf essential oils of Murraya koenigii (L.) Spreng and Murraya paniculata (L.) Jack. Bangladesh Journal of Pharmacology 3: 59-63. https://doi.org/10.3329/bjp.v3i2.841

5. Evans, M. E. K.; Falk, D. A.; Swetnam, T. L.; Babs, F.; Holsinger, K. E. (2017) Fusing tree-ring and forest inventory data to infer influences on tree growth. Ecosphere 8: 1-20. https://doi.org/10.1002 / ecs2.1889

6. Figueiredo Filho, A.; Retslaff, F. de S.; Retslaff, F. de S.; Longhi-Santos, T.; Stepka, T. F. (2017) Crescimento e idade de espécies nativas regenerantes sob plantio de Araucaria angustifolia no Paraná. Floresta e Ambiente 24: p. e00104814. https://doi.org/10.1590/2179-8087.104814

7. Gengo, R. DE C.; Henkes, J. A. (2013) A utilização do paisagismo como ferramenta na preservação e melhoria ambiental em área urbana. Revista Gestão e Sustentabilidade Ambiental 1: 55-81. http://dx.doi.org/10.19177/rgsa.v1e2201255-81

8. Gonçalves, E. de O.; Paiva, H. N. de; Neves, J. C. L.; Gomes, J. M. (2008) Crescimento de mudas de angico-vermelho (Anadenanthera macrocarpa (Benth .) Brenan ) sob diferentes doses de macronutrientes. Árvore 32: 1029-1040. https://doi.org/10.1590/S0100-67622008000600008

9. Gratani, L.; Varone, L. (2006) Carbon sequestration by Quercus ilex L. and Quercus pubescens Willd. and their contribution to decreasing air temperature in Rome. Urban Ecosystems 9: 27-37. https://doi.org/10.1007/s11252-006-5527-2

10. Hess, A. F.; Schneider, P. R. (2010) Crescimento em volume de Araucaria angustifolia (Bertol.) Kuntze em três regiões do Rio Grande do Sul, Brasil. Ciência Florestal 20: 107-122. https://doi.org/10.5902/198050981765

11. lakovoglou, V.; Thompson, J.; Burras, L.; Kipper, R. (2001) Factors related to tree growth across urbanrural gradients in the Midwest, USA. Urban Ecosystems 5: 71-85. https://doi.org/10.1023/A:1021829702654

12. IBGE - Instituto Brasileiro de Geografia e Estatística. (2012) Manual Técnico da Vegetação Brasileira. $2^{\mathrm{a}}$ ed. Rio de Janeiro: 275p.

13. Kohl, M. ; Neupane, P.R. ; Lotfiomran, N. (2017) The impact of tree age on biomass growth and carbon accumulation capacity: A retrospective analysis using tree ring data of three tropical tree species grown in natural forests of Suriname. PLoS ONE 12: p.e0181187. https://doi.org/10.1371/journal.pone.0181187

14. Lacy, P. de; Shackleton, C. M. (2014) The comparative growth rates of indigenous street and garden trees in Grahamstown, South Africa. South African Journal of Botany 92: 94-96. https://doi.org/10.1016/j.sajb.2014.02.007

15. Lawrence, A. B.; Escobedo, F. J.; Stuadhammer, C. L.; Zipperer, W. (2012) Analyzing growth and mortality in a subtropical urban forest ecosystem. Landscape and Urban Planning 104: 85-94. https://doi.org/10.1016/j.landurbplan.2011.10.004

16. Martin, P.H.; Canham, C.D.; Kobe, R.K. (2010) Divergence from the growth-survival trade-off and extreme height growth rates drive patterns of exotic tree invasivos in closed-canopy forests. Journal 
of Ecology 98: 778-789. https://doi.org/ 10.1111/J.1365-2745.2010.01666.X

17. McHale, M. R.; Burke, I. C.; Lefsky, M. A.; Peper, P. J. (2009) Urban forest biomass estimates: is it important to use allometric relationships developed specifically for urban trees? Urban Ecosyst 12 : 95-113. https://doi.org/ 10.1007/s11252-009-0081-3

18. MOBOT - Missouri Botanical Garden (2012). Plant Science Database - W3 TRÓPICOS. Disponível em: http://www.mobot.org. Acess: May, 2018.

19. Morgenroth, J.; Buchan, G.; Scharenbroch, B. C. (2013) Belowground effects of porous pavements Soil moisture and chemical properties. Ecological Engineering 51: 221-228.

https://doi.org/10.1016/j.ecoleng.2012.12.041

20. Muñoz, N.G.; Calderón, J.C.L.; Díez, P. C.; Klaassen, U. S. (2015) Contrasting secondary growth and water use efficiency patterns in native and exotic trees co-occurring in inner Spain riparian forests. Forest Systems 24: p.e. 017. http://dx.doi.org/10.5424/fs/2015241-06586

21. Zimmermann, N. E.; Yoccoz, N.G.; Edwards, T.C.; Meier, J.R.; Thuiller, E.S.; Guisan, W.; Schmatz, A.; Pearman, D.R.. (2009) Climatic extremes improve predictions of spatial patterns of tree species. Proceedings of the National Academy of Sciences 106: 19723-19728. https://doi.org/10.1073/pnas.0901643106

22. Oliveira, J. N. B. (2011) Anatomia das plantas superiores. Coingra Ltda. Ponta Delgada.

23. Pretzsch, H. ; Biber, P. ; Uhl, E. ; Dahlhausen, J. ; Schütze, G. ; Perkins, D. ; Rötzer, T. ; Caldentey, J. ; Koike, T. ; Con, T.V. ; Chavanne, A. ; Toit, B.D. ; Foster, K. ; Lefer, B. (2017) Climate change accelerates growth of urban trees in metropolises worldwide. Scientific Reports 7: 15403 (10). https://doi.org/10.1038/s41598-017-14831-w

24. Pretzsch, H.; Biber, P.; Uhl, E.; Dahlhausen, J.; Rötzer, T.; Caldentey, J.; Koike, T.; van Con, T.; Chavanne, A.; Seifert, T.; du Toit, B.; Farnden, C.; Pauleit, S. (2015) Crown size and growing space requirement of common tree species in urban centres, parks, and forests. Urban Forestry and Urban Greening 14:466-479. https://doi.org/10.1016/j.ufug.2015.04.006

25. Rossatto, D. R.; Tsuboy, M. S. F.; Frei, F. (2008) Arborização urbana na cidade de Assis - SP: Uma abordagem quantitativa. Revista da Sociedade Brasileira de Arborização Urbana 3: 1-16. http://dx.doi.org/10.5380/revsbau.v3i3.66359

26. Rötzer, T ; Rahman, M.A ; Moser-Reischl, A ; Pauleit, S ; Pretzsch, H. (2019) Process based simulation of tree growth and ecosystem services of urban trees under present and future climate conditions. The Science of the total environment 676: 651-664. https://doi.org/10.1016/j.scitotenv.2019.04.235

27. Rust, S. (2014) Analysis of regional variation of height growth and slenderness in populations of six urban tree species using a quantile regression approach. Urban Forestry and Urban Greening 13: 336-343. https://doi.org/10.1016/j.ufug.2013.12.003

28. Semenzato, P.; Cattaneo, D.; Dainese, M. (2011) Growth prediction for five tree species in an Italian urban forest. Urban Forestry and Urban Greening 10: 169-176. https://doi.org/10.1016/j.ufug.2011.05.001 
29. Souza, C. R. de; Lima, R. M. B. de; Azevedo, C. P. de; Rossi, L. M. B. (2008) Desempenho de espécies florestais para uso múltiplo na Amazônia. Scientia Forestalis 36:7-14.

30. UFV. Boletim meteorológico 2018. Disponível em: <http://www.bibliotekevirtual.org/index.php/201302-07-03-02-35/2013-02-07-03-03-11/169-rcm/v04n01/632-v04n01a01.html>. Acess: July, 2018.

31. Viswanathan, B.; VoldeR, A.; Watson, W. T.; Aitkenhead-Peterson, J. A. (2011) Impervious and pervious pavements increase soil $\mathrm{CO}_{2}$ concentrations and reduce root production of American sweetgum (Liquidambar styraciflua). Urban Forestry and Urban Greening 10: 133-139. https://doi.org/10.1016/j.ufug.2011.01.001

32. Vitali, V.; Büntgen, U.; Bauhus, J. (2018) Seasonality matters-The effects of past and projected seasonal climate change on the growth of native and exotic conifer species in Central Europe. Dendrochronologia 8: 1-9. https://doi.org/10.1016/j.dendro.2018.01.001

33. Vogt, J. M.; Watkins, S. L.; Mincey, S. K.; Patterson, M. S. Fischer, B. C. (2015) Explaining planted-tree survival and growth in urban neighborhoods: A social-ecological approach to studying recentlyplanted trees in Indianapolis. Landscape and Urban Planning 136: 130-143. https://doi.org/10.1016/j.landurbplan.2014.11.021

34. Williams, A.P.; Allen, C.D.; Macalady, A.K.; Griffin, D.; Woodhouse, C.A.; Meko, D.M.; Swetnam, T.W.; Rauscher, S.A.; Seager, R.; Grissino-Mayer, H.D.; Dean, J.S.; Cook, E.R.; Gangodagamage, C.; Cai, M.; McDowell, N.G. (2012) Temperature as a potent driver of regional forest drought stress and tree mortality. Nature Climate Change 3: 292-297. https://doi.org/10.1038/nclimate1693

35. Xiao, Q. ; McPherson, E. (2002) Rainfall interception by Santa Monica's municipal urban forest. Urban Ecosystems 6: 291-302. https://doi.org/10.1023/B:UEC0.0000004828.05143.67 